\title{
Perfect order fulfillment in construction supply chain performance
}

\author{
Moh Nur Sholeh", Fardzanela Suwarto \\ Civil and Planning Department, Vocational School, Diponegoro University, Semarang 50275, \\ Indonesia
}

\begin{abstract}
The problem of construction supply chains is the fragmentation of unsustainable projects such as manufacturing. Therefore it is necessary to have supply chain performance indicator standards related to the procurement of materials that can be used as a reference for the performance of a project or contractor. The purpose of this study is to measure the performance of the construction supply chain with the perfect order fulfillment (POF) indicator adopted from the Supply Chain Operations Reference (SCOR) 12.0. The adoption stage starts from the definition in construction to the calculation of indicators in the project. The results showed that suppliers of steel and ready mix concrete at close range from the project had better performance. In the case study, the perfect order fulfillment performance of steel suppliers with a distance of $345 \mathrm{~km}$ is worth $89.476 \%$ while suppliers with a distance of $540 \mathrm{~km}$ are worth $87.535 \%$. The supplier of ready mix concrete within $7.3 \mathrm{~km}$ is worth $95.355 \%$ and the supplier with a distance of $15.7 \mathrm{~km}$ is $91.705 \%$.
\end{abstract}

\section{Introduction}

The construction industry is called a fragmented industry because it is not continuous like the manufacturing industry $[1,2]$. This fragmentation is a challenge and at the same time, there must be a solution. One approach solution is construction supply chain management that needs performance indicators. Construction supply chain management is an integrated method from upstream to downstream that involves the stakeholders in the construction project, which are owner, consultant, contractor, subcontractor, and supplier for the success of the project [3]. The construction supply chain consists of material, information, money, and labor flows. Material flow has had an impact on supply chain performance and better lead times that have been studied in Kenya [4]. The quality of the information received will increase the efficiency of project procurement [5].

Material management is a big challenge in managing construction projects due to the large volume and cost. Material supply chain practices in the construction industry have been investigated to explore the impact of project performance in India [6]. In this era, it is very much needed project management based on sustainable construction that leads to sustainable material In this era, it is very much needed project management based on sustainable

* Corresponding author: mohnursholeh@live.undip.ac.id 
construction that leads to sustainable material $[7,8]$. It aims to reduce construction waste caused by the material. As it is known that construction material waste is very disruptive to the project and requires special handling. Simulations and model scenarios have been carried out for the reduction of material waste caused by changes in worker waste behavior by $34.58 \%$ and followed by personal factors, organizational culture, and attitude variables [9]. Therefore we need to measure the performance of the construction supply chain that focuses on good material procurement.

Supply Chain Operations Reference (SCOR) 12.0 has a performance indicator that is perfect order fulfillment $[10,11]$. The perfect order fulfillment indicator from SCOR is widely applied in manufacturing companies. Case studies have been carried out to optimize order fulfillment in a global retail supply chain with the result that $47 \%$ focus on developing the company's internal business [12]. The development of research into online order fulfillment of future behavior has identified the successes and failures [13]. This study aims to calculate the construction supply chain performance on the material aspects using the SCOR indicator, perfect order fulfillment. This indicator was adopted directly from SCOR 12.0 which was then defined to applications in construction. Language and depth measurement adjustments are made to facilitate understanding of the project. So this research applies a case study to measure the performance of perfect order fulfillment deeper.

\section{Perfect order fulfillment by SCOR}

The Supply Chain Operations Reference (SCOR) 12.0 process is integrating plan, source, make, deliver, return, and enable suppliers to customers [10]. This process connects the internal and external of the company. SCOR consists of 4 levels: level 1 as major processes, level 2 as categories, level 3 as elements, and level 4 as improvement tools or activities. The SCOR structure includes performances, processes, practices, and people. The perfect order fulfillment indicator is on reliability performance which is the company's ability to fulfill as planned. This typical performance focuses on timeliness, quality, and quantity. Therefore perfect order fulfillment is defined as the percentage of orders fulfilling shipping performance with complete and accurate documentation and there is no shipping damage [14]. This component includes all material items and quantities on time.

Table 1. Adoption of the hierarchy of perfect order fulfillment to construction [10]

\begin{tabular}{|l|l|l|l|}
\hline Code & \multicolumn{1}{|c|}{ Hierarchy } & \multicolumn{1}{|c|}{$\begin{array}{c}\text { Definition in } \\
\text { construction }\end{array}$} & \multicolumn{1}{c|}{ Calculation } \\
\hline POF 1 & $\begin{array}{l}\text { \% of orders } \\
\text { delivered in full }\end{array}$ & $\begin{array}{l}\text { Percentage of customer } \\
\text { orders received in the } \\
\text { specified quantity. }\end{array}$ & $\begin{array}{l}\text { [Total number of orders delivered in } \\
\text { full] / [Total number of orders } \\
\text { delivered] x 100\% }\end{array}$ \\
\hline POF 2 & $\begin{array}{l}\text { Delivery } \\
\text { performance to } \\
\text { customer commit } \\
\text { date }\end{array}$ & $\begin{array}{l}\text { Percentage of customer } \\
\text { orders filled by } \\
\text { suppliers according to } \\
\text { the date of commitment. } \\
\text { thotal number of orders delivered on } \\
\text { the original commitment date] / } \\
\text { [Total number of orders } \\
\text { delivered] x 100\% }\end{array}$ \\
\hline POF 3 & $\begin{array}{l}\text { Documentation } \\
\text { accuracy }\end{array}$ & $\begin{array}{l}\text { Percentage of orders on } \\
\text { time along with } \\
\text { accurate documentation } \\
\text { that supports orders. }\end{array}$ & $\begin{array}{l}\text { [Total number of orders delivered } \\
\text { with accurate documentation] / [Total } \\
\text { number of orders delivered] } \\
\text { x 100\% }\end{array}$ \\
\hline POF 4 & Perfect condition & $\begin{array}{l}\text { Percentage of orders } \\
\text { sent in an undamaged } \\
\text { condition that meets } \\
\text { specifications and can } \\
\text { be installed perfectly. }\end{array}$ & $\begin{array}{l}\text { [Number of orders delivered in } \\
\text { perfect condition] / [Number of } \\
\text { orders delivered] x 100\% }\end{array}$ \\
\hline
\end{tabular}


The perfect order fulfillment formula is:

[Total Perfect Orders] / [Total Number of Orders] x 100\%

The criteria that are said to be perfect must meet (1) complete deliveries in quantity, (2) delivered on time to the customer, (3) be accompanied by accurate supporting documents, (4) no damage if installed.

\section{Case study methodology}

Based on survey results to respondents, perfect order fulfillment can be used as an indicator of supply chain performance measurement. That is because the number of products delivered in full will affect the smooth running of the project. If there is no material implementation in the field, it will produce idle where the work will be hampered and costs will come out due to indirect waste due to unemployed workers. This research case study was carried out in a building construction project located in Semarang, Central Java, Indonesia. In this study, the focus is on the project supply chain activities with reinforcing steel and ready-mix concrete material. This is because steel is the main material in the main work of the project, for example, casting [15]. Besides that ready mix concrete is a material that is almost always used in projects so that the flow of material is very important [16].

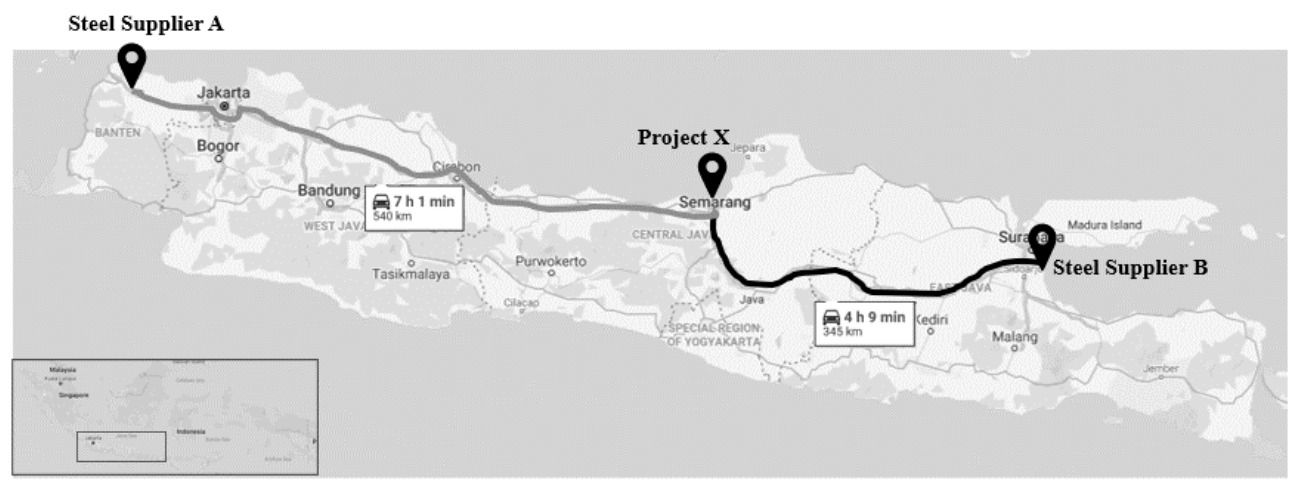

Fig. 1. Reinforcing steel supply chain scheme in Project $X$

The project collaborates with two reinforcing steel suppliers namely steel supplier A located in Tangerang, Banten Province with a distance of $540 \mathrm{~km}$ and steel supplier B located in Sidoarjo, East Java Province with a distance of $345 \mathrm{~km}$. The explanation is simply illustrated in Figure 1. Expedition of shipping of reinforcing steel material from the supplier's warehouse to the project site by land. The precast wall production location is outside the project fence because the location is very narrow so it does not allow the production of the precast wall within the project.

The distance between the precast wall production site and the project location is $7 \mathrm{Km}$. The project also works with two ready mix concrete suppliers. Ready-mix concrete supplier A is located within the city of Semarang within $7.3 \mathrm{~km}$ from Project X. While ready mix concrete supplier B is located in Semarang Regency, a neighboring city within $15.7 \mathrm{~km}$ as in Figure 2. Readymix concrete material shipment by truck mixer by landline corresponding allowable classpath is at least grade II. The choice of transportation route greatly determines the speed of material delivery. Luckily on the island of Java, toll roads have been built so that transportation flows are faster, even though shipping costs are more expensive due to paying toll rates. 
In two types of material supply chains, reinforcing steel, and ready-mix concrete, performance measurements are carried out on how the supplier can meet the material perfectly and on time. The research method was carried out by taking data in Project X and the suppliers concerned. Respondents in Project $X$ are project managers and heads of materials procurement, while suppliers are in the material delivery department. This aims to match the data that has been obtained so that it is more accurate. The data obtained is the total number of orders delivered according to each hierarchy in Table 1 and the total number of orders delivered. The four hierarchies are counted for each supplier and then averaged what their perfect order fulfillment is.

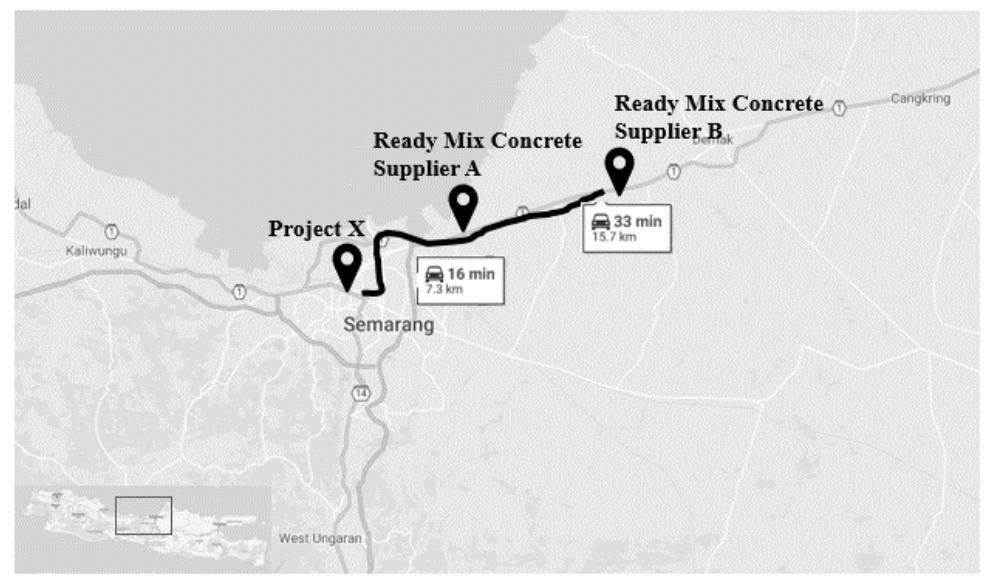

Fig. 2. Ready-mix concrete supply chain scheme in Project $X$

\section{Implementing the perfect order fulfillment indicator}

\subsection{Perfect order fulfillment calculation}

In Project X, ordering reinforced steel and ready-mix concrete are done through a centralized framework contract system between the main company of Project $X$ and the selected steel suppliers. This contract resulted in the unit price of the material being agreed by both parties, the project only needs to make the purchase order according to the work requirements. Ordering material for precast wall work (steel and ready-mix concrete) has a large impact on the duration of the project because steel and ready-mix concrete are the main material forming precast walls. Therefore it needs proper planning so that the project can be completed according to the specified target. Large-scale projects need good and integrated material management.

The results of the calculation of perfect order fulfillment on reinforced steel and readymix concrete materials are as Table 2. Based on this table, it can be said that the performance of perfect order fulfillment of steel B suppliers located in Sidoarjo Regency, East Java Province is better than steel suppliers A with value $89.476 \%$. There is a difference of $1,941 \%$ between suppliers B and A which shows how the perfect order fulfillment performance in Project X. Factors that lead to the suppliers' sites are within a shorter project. To achieve this value, some of the things done by the Project $\mathrm{X}$ team are improving communication with suppliers using facilities such as telephone, e-mail, and WhatsApp. It also tightens quality control by taking steel samples every time for tensile \& bending tests in the laboratory. 
Table 2. Calculation of perfect order fulfillment of steel suppliers

\begin{tabular}{|l|r|r|r|r|r|r|}
\hline \multirow{2}{*}{ Hierarchy } & \multicolumn{3}{|c|}{ Steel supplier A } & \multicolumn{3}{c|}{ Steel supplier B } \\
\cline { 2 - 7 } & $\begin{array}{c}\text { Total } \\
\text { perfect } \\
\text { orders }\end{array}$ & $\begin{array}{c}\text { Total } \\
\text { number of } \\
\text { orders }\end{array}$ & Calculation & $\begin{array}{c}\text { Total } \\
\text { perfect } \\
\text { orders }\end{array}$ & $\begin{array}{c}\text { Total } \\
\text { number of } \\
\text { orders }\end{array}$ & Calculation \\
\hline & $(1)$ & $(2)$ & $\begin{array}{c}(3)= \\
(1) /(2) * 100 \%\end{array}$ & $(4)$ & $(5)$ & $\begin{array}{c}(6)= \\
(4) /(5) * 100 \%\end{array}$ \\
\hline POF 1 & $17,350 \mathrm{~kg}$ & $18,250 \mathrm{~kg}$ & $95.07 \%$ & $17,450 \mathrm{~kg}$ & $18,250 \mathrm{~kg}$ & $95.62 \%$ \\
\hline POF 2 & 4 times & 5 times & $80 \%$ & 5 times & 6 times & $83.33 \%$ \\
\hline POF 3 & 4 times & 5 times & $80 \%$ & 5 times & 6 times & $83.33 \%$ \\
\hline POF 4 & $17,350 \mathrm{~kg}$ & $18,250 \mathrm{~kg}$ & $95.07 \%$ & $17,450 \mathrm{~kg}$ & $18,250 \mathrm{~kg}$ & $95.62 \%$ \\
\hline & Perfect order fulfillment & $87.535 \%$ & Perfect order fulfillment & $89.476 \%$ \\
\hline
\end{tabular}

In the project, there was damage to the shipping of steel suppliers. In further interviews found several reasons why steel shipments could be a little defective and not on time. These things are influenced by technical errors in production, the ability of human resources suppliers, the provision of a shipping fleet, and the lack of communication between suppliers and contractors [17].

While the calculation of the performance of ready mix concrete suppliers on the perfect order fulfillment indicator is as follows.

Table 3. Calculation of perfect order fulfillment of ready mix concrete suppliers

\begin{tabular}{|l|c|r|r|r|r|r|}
\hline \multirow{2}{*}{ Hierarchy } & \multicolumn{3}{|c|}{ Ready-mix concrete supplier A } & \multicolumn{2}{c|}{ Ready-mix concrete supplier B } \\
\cline { 2 - 7 } & $\begin{array}{c}\text { Total } \\
\text { perfect } \\
\text { orders }\end{array}$ & $\begin{array}{c}\text { Total } \\
\text { number of } \\
\text { orders }\end{array}$ & Calculation & $\begin{array}{c}\text { Total } \\
\text { perfect } \\
\text { orders }\end{array}$ & $\begin{array}{c}\text { Total } \\
\text { number of } \\
\text { orders }\end{array}$ & Calculation \\
\hline & $(1)$ & $(2)$ & $\begin{array}{c}(3)= \\
(1) /(2) * 100 \%\end{array}$ & $\begin{array}{c}(4) \\
(5)\end{array}$ & $\begin{array}{c}(6)= \\
(4) /(5) * 100 \%\end{array}$ \\
\hline POF 1 & $134 \mathrm{~m}^{3}$ & $140 \mathrm{~m}^{3}$ & $95.71 \%$ & $124 \mathrm{~m}^{3}$ & $132 \mathrm{~m}^{3}$ & $93.94 \%$ \\
\hline POF 2 & 19 times & 20 times & $95 \%$ & 17 times & 19 times & $89.47 \%$ \\
\hline POF 3 & 19 times & 20 times & $95 \%$ & 17 times & 19 times & $89.47 \%$ \\
\hline POF 4 & $134 \mathrm{~m}^{\mathrm{s}}$ & $140 \mathrm{~m}^{3}$ & $95.71 \%$ & $124 \mathrm{~m}^{3}$ & $132 \mathrm{~m}^{3}$ & $93.94 \%$ \\
\hline & Perfect order fulfillment & $95.355 \%$ & Perfect order fulfillment & $91.705 \%$ \\
\hline
\end{tabular}

Based on Table 3, it can be said that the performance of perfect order fulfillment of ready mix concrete A suppliers located in which is located in the city of Semarang is better than steel suppliers B with value $95.355 \%$. The main differentiating factors of these two suppliers are due to different locations. Concrete supplier A is closer than concrete supplier B.

To achieve this value, some of the things done by the Project $\mathrm{X}$ team are sending monthly and weekly casting schedules to suppliers. Besides, the project team also confirmed 1x24 hours before casting was carried out every day. When concrete arrives at the project, the logistics team measures the volume of concrete by a mathematical calculation and compares it with the poured concrete in the casting bucket. The quality control team took a concrete 
sample for a pressure test in the material laboratory [18]. In this scenario, delays still occur frequently. Due to the distance between the batching plant and the fabrication site so that traffic and supplier response speed becomes one of the significant variables that influence the accuracy and quality of the concrete when it arrives at the fabrication site. Imperfect delivery will affect the execution time increases, the cost of implementation increases and the quality of work is not as planned. These things are usually influenced by the capacity of existing human resources at suppliers and contractors, overloaded production capacity, inadequate availability of raw materials, and inadequate communication [19].

\subsection{Mitigation perfect order fulfillment issues}

Based on the results of calculations and explanations for the procurement of reinforcing steel and ready-mix concrete materials for precast wall work, many factors affect the accuracy of procurement. These factors are the number of reinforcing steel suppliers and ready mix concrete used, the distance between the project location and the location of the supplier, the distance between the production location of the precast wall with the supplier's location, the shipping expedition route used, the number and condition of the fleet owned by the supplier, and the ability of the operator \& supplier worker. The management of the supply chain of construction materials has now developed rapidly using technologies such as Building Information Modeling (BIM) and Geographic Information System (GIS) [20][21]. Therefore the contractor needs to make the best supplier selection and be closer to the project. This aims to facilitate the management of material shipments.

\section{Conclusion}

This research has sought to measure the performance of perfect order fulfillment on suppliers of steel and ready-mix concrete. The perfect order fulfillment indicator has four levels of responsibility, namely $\%$ of orders delivered in full, delivery performance to customer commit date, documentation accuracy, and perfect condition. The fourth calculation is the total perfect order value of the total number of orders. The case study results calculate that suppliers of steel and ready mix concrete that is closer to the project site result in better perfect order fulfillment performance. Steel suppliers in Sidoarjo with a distance of $345 \mathrm{~km}$ are worth $89.476 \%$ while steel suppliers in Tangerang with a distance of $540 \mathrm{~km}$ are worth $87.535 \%$. Supplier of ready mix concrete in Semarang City with a distance of $7.3 \mathrm{~km}$ is worth $95.355 \%$, while suppliers of ready mix concrete in Demak with a distance of $15.7 \mathrm{~km}$ are worth $91.705 \%$.

In the performance indicators in the Supply Chain Operations Reference (SCOR) 12.0 other indicators have the opportunity for further research in the application in the construction supply chain. This research still focuses on the supply chain process in Java alone even though Indonesia consists of many islands. So it is very interesting to research the measurement of inter-island construction supply chain performance. The location of suppliers and projects that are getting further away will certainly be a lot of challenges in the process of sending materials and communications. This research will be heavily influenced by the national construction supply chain and government policy. The supply and demand of national construction materials will determine the success of the supply chain in each the project. 


\section{References}

1. A. M. Alashwal, H. A. Rahman, and A. M. Beksin, "Knowledge sharing in a fragmented construction industry: On the hindsight," vol. 6, no. 7, pp. 1530-1536, (2011).

2. M. Nawi, M. Nasrun, N. H. Baluch, and A. Y. Bahaudin, "Impact of fragmentation issue in construction industry: An overview," in MATEC web of conferences, (2014), vol. 15.

3. P. Behera, R. Mohanty, and A. Prakash, "Understanding construction supply chain management," Prod. Plan. Control, vol. 26, no. 16, pp. 1332-1350, (2015).

4. A. J. Olang'o, O. Arvinlucy, and M. Peterson, "Material Flow, Supply Chain Performance and Lead Time of Road Construction Projects in Kenya," African J. Bus. Ind., vol. 2, no. 1, pp. 17-33, (2016).

5. S. Titus and J. Bröchner, "Managing information flow in construction supply chains," Constr. Innov., vol. 5, no. 2, pp. 71-82, (2005).

6. S. Kaushik, "Material Supply Chain Practices in the Construction Industry," Int. Res. J. Eng. Technol., vol. 5, no. 7, pp. 543-554, (2018).

7. M. A. Wibowo, M. N. Sholeh, Elizar, and H. S. Adji, "Supply chain management strategy for recycled materials to support sustainable construction," Procedia Eng., (2017).

8. K. Govindan, K. M. Shankar, and D. Kannan, "Sustainable material selection for construction industry - A hybrid multi criteria decision making approach," Renew. Sustain. Energy Rev., vol. 55, pp. 1274-1288, (2016).

9. H. Suciati, T. J. W. Adi, and I. P. A. Wiguna, "A Dynamic Model for Assessing the Effects of Construction Worker Waste Behavior to Reduce Material Waste," Int. J. Adv. Sci. Eng. Inf. Technol., vol. 8, no. 2, (2018).

10. APICS, Supply Chain Operations Reference (SCOR) Version 12.0. 2017.

11. Supply Chain Council, "Supply Chain Operations Reference Model," Supply Chain Oper. Manag., pp. 1-976, (2012).

12. Y. Amer, L. Luong, and S.-H. Lee, "Case study: Optimizing order fulfillment in a global retail supply chain,” Int. J. Prod. Econ., vol. 127, no. 2, pp. 278-291, (2010).

13. S. Rao, S. E. Griffis, and T. J. Goldsby, "Failure to deliver? Linking online order fulfillment glitches with future purchase behavior," J. Oper. Manag., vol. 29, no. 7-8, pp. 692-703, (2011).

14. Y. Amer, L. Luong, S.-H. Lee, and M. A. Ashraf, "Optimizing order fulfillment using design for six sigma and fuzzy logic," Int. J. Manag. Sci. Eng. Manag., vol. 3, no. 2, pp. 83-99, (2008).

15. N. Baddoo, "Stainless steel in construction: A review of research, applications, challenges and opportunities," J. Constr. Steel Res., vol. 64, no. 11, pp. 1199-1206, (2008).

16. M. N. Sholeh, S. Fauziyah, B. Dharmo, P. Widodo, and I. Christiawan, "The Development of Construction Supply Chain Model on Ready Mix Concrete with Value Stream Mapping Method," vol. 24, no. 12, pp. 9695-9697, (2018).

17. E. Papadonikolaki and H. Wamelink, "Inter- and intra-organizational conditions for supply chain integration with BIM Inter- and intra-organizational conditions for supply chain integration with BIM," Build. Res. Inf., vol. 45, no. 6, pp. 649-664, (2017).

18. J. S. Oakland and M. Marosszeky, Total construction management: Lean quality in construction project delivery. Routledge, (2017). 
19. D.-R. I. Stamatiou, S. P. Gayialis, S. T. Ponis, N. A. Panayiotou, and I. P. Tatsiopoulos, "A reference model for supplier/customer relationship management in construction supply chains," in The 5th International Symposium and 27th National Conference on Operation Research, 2016, pp. 78-84.

20. E. P. Karan, J. Irizarry, and J. Haymaker, "BIM and GIS Integration and Interoperability Based on Semantic Web Technology," J. Comput. Civ. Eng., vol. 30, no. 3, p. 04015043 , (2016).

21. J. Irizarry, E. P. Karan, and F. Jalaei, "Integrating BIM and GIS to improve the visual monitoring of construction supply chain management," Autom. Constr., vol. 31, pp. 241254, (2013). 